\title{
Article \\ Human Islet Amyloid Polypeptide Overexpression in INS-1E Cells Influences Amylin Oligomerization under ER Stress and Oxidative Stress
}

\author{
Yeong-Min Yoo ${ }^{1, *(D)}$ and Seong Soo Joo ${ }^{2, *}$ \\ 1 East Coast Life Sciences Institute, College of Life Science, Gangneung-Wonju National University, \\ Gangneung 25457, Gangwon-do, Korea \\ 2 Department of Marine Life Sciences, College of Life Science, Gangneung-Wonju National University, \\ Gangneung 25457, Gangwon-do, Korea \\ * Correspondence: yooym@gwnu.ac.kr (Y.-M.Y.); ssj66@gwnu.ac.kr (S.S.J.); \\ Tel.: +82-10-2494-5309 (Y.-M.Y.); +82-33-640-2856 (S.S.J.); Fax: +82-33-640-2849 (Y.-M.Y. \& S.S.J.)
}

Citation: Yoo, Y.-M.; Joo, S.S. Human Islet Amyloid Polypeptide Overexpression in INS-1E Cells Influences Amylin Oligomerization under ER Stress and Oxidative Stress. Int. J. Mol. Sci. 2021, 22, 11341. https://doi.org/10.3390/ ijms222111341

Academic Editor: Luigi Casella

Received: 16 September 2021

Accepted: 19 October 2021

Published: 20 October 2021

Publisher's Note: MDPI stays neutral with regard to jurisdictional claims in published maps and institutional affiliations.

Copyright: (c) 2021 by the authors. Licensee MDPI, Basel, Switzerland. This article is an open access article distributed under the terms and conditions of the Creative Commons Attribution (CC BY) license (https:/ / creativecommons.org/licenses/by/ $4.0 /)$.

\begin{abstract}
Human amylin or islet amyloid polypeptide (hIAPP) is synthesized in the pancreatic $\beta$-cells and has been shown to contribute to the pathogenesis of type 2 diabetes (T2D) in vitro and in vivo. This study compared amylin oligomerization/expression and signal transduction under endoplasmic reticulum (ER) stress and oxidative stress. pCMV-hIAPP-overexpressing INS-1E cells presented different patterns of amylin oligomerization/expression under ER stress and oxidative stress. Amylin oligomerization/expression under ER stress showed three amylin oligomers of less than $15 \mathrm{kDa}$ size in pCMV-hIAPP-overexpressing cells, while one band was detected under oxidative stress. Under ER stress conditions, HIF1 $\alpha$, p-ERK, CHOP, Cu/Zn-SOD, and Bax were significantly increased in pCMV-hIAPP-overexpressing cells compared to the pCMV-Entry-expressing cells (control), whereas p-Akt, p-mTOR, Mn-SOD, catalase, and Bcl-2 were significantly decreased. Under oxidative stress conditions, HIF1 $\alpha$, p-ERK, CHOP, Mn-SOD, catalase, and Bcl-2 were significantly reduced in pCMV-hIAPP-overexpressing cells compared to the control, whereas p-mTOR, Cu/Zn-SOD, and Bax were significantly increased. In mitochondrial oxidative phosphorylation (OXPHOS), the mitochondrial complex I and complex IV were significantly decreased under ER stress conditions and significantly increased under oxidative stress conditions in pCMV-hIAPP-overexpressing cells compared to the control. The present study results demonstrate that amylin undergoes oligomerization under ER stress in pCMV-hIAPP-overexpressing cells. In addition, human amylin overexpression under ER stress in the pancreatic $\beta$ cells may enhance amylin protein aggregation, resulting in $\beta$-cell dysfunction.
\end{abstract}

Keywords: human amylin or islet amyloid polypeptide; overexpression; ER stress; oxidative stress; INS-1E cells

\section{Introduction}

Although human amylin or islet amyloid polypeptide (hIAPP) and rat IAPP (rIAPP) have $83 \%$ sequence identity, hIAPP rapidly aggregates into amyloid fibrils in vitro while rIAPP does not form fibrils under the same experimental conditions [1-3]. When comparing these two peptides sequences, the variation is evident in the region spanning residues 20-29. Westermark et al. evaluated the aggregation ability of peptides containing residues 20-29 and confirmed that they could form amyloid fibrils in vitro [4]. Thus, amino acid residues 20-29 of hIAPP play an essential role in the aggregation of amylin into amyloid and may act as a significant determinant of amyloid growth [2,5]. Previous studies have shown that hIAPP aggregation is initiated by an intrinsically disordered 37 amino acid peptide and the chemical properties of amino acids, including charge, hydrophobicity, and aromaticity, influence hIAPP aggregation $[2,6]$. Therefore, the molecular determinant in the production of hIAPP amyloid deposits is the amino acid composition of the peptide. For instance, some 
studies have suggested that N-terminal domain variants are less toxic to INS-1 cells but are involved in the modulation of toxicity and are in the critical position [2,7-9]. In particular, in a recent study, Nguyen et al. [10] reported that adding a single methylene group by substituting Gln for Asn at position 21 (N21Q) of IAPP resulted in the formation of fibrils with potent cytotoxicity to INS-1E cells. They suggested that N21Q fibrillar structure enables conformational self-assembly, and the resulting IAPP assembly can be cytotoxic.

Lorenzo et al. [11] demonstrated that hIAPP is only toxic to beta cells of the adult pancreas in rats and humans. Further, the result of their study proved that selective cytotoxicity is induced by the deposition of amyloid fibrils from amylin peptides and occurs by direct contact with the cell surface. Therefore, this result indicates that the presence of amylin fibrils in the pancreas can lead to islet cell dysfunction and death, leading to type 2 diabetes (T2D) [12,13]. In addition, the cytotoxicity of hIAPP in pancreatic $\beta$ cells is enhanced by several cellular stress conditions, including islet inflammation, oxidative stress, mitochondrial dysfunction, DNA damage, apoptosis, endoplasmic reticulum (ER) stress, and plasma membrane disruption [14,15]. Extracellular hIAPP aggregation is involved with ER stress response in mouse beta cells [16,17]. In addition, toxic intracellular aggregates were formed in rat pancreatic beta-cells overexpressing hIAPP, which induces defective insulin and IAPP secretion by reacting to glucose [18]. Nevertheless, the role of hIAPP overexpression and ER stress induction has not been fully elucidated.

This study compared the amylin oligomerization/expression and cell signaling pathway under ER stress and oxidative stress conditions. ER stress is induced by thapsigargin or tunicamycin treatments, while oxidative stress is caused by serum deprivation, nitric oxide, or hydrogen peroxide treatments.

\section{Results}

\subsection{The hIAPP Oligomerization/Expression and Signal Pathways under ER Stress Conditions}

First, we investigated hIAPP oligomerization/expression and signal pathways under ER stress in INS-1E cells. ER stress is induced by thapsigargin $(1 \mu \mathrm{M})$ or tunicamycin $(2 \mu \mathrm{g} / \mathrm{mL})$ treatments with/without 4-phenylbutyric acid (4-PBA, $20 \mu \mathrm{M})$. pCMV6-Entry and pCMV-hIAPP vectors were stably transfected in the INS-1E cells and selected with G418. The introduced hIAPP gene was confirmed by hIAPP overexpression determined using Western blot. The cell viability showed no significant change by thapsigargin or tunicamycin treatments with/without 4-PBA (Figure 1). Amylin oligomerization/expression showed three bands of amylin oligomers of less than $15 \mathrm{kDa}$ size in INS-1E cells. HIF1 $\alpha$, p-ERK, CHOP, Cu/Zn-SOD, and Bax were significantly increased in the pCMV-hIAPPoverexpressing INS-1E cells compared to the pCMV-Entry-expressing INS-1E cells (the control), whereas p-Akt, p-mTOR, Mn-SOD, catalase, and Bcl-2 were significantly decreased (Figures 2 and 3). In mitochondrial oxidative phosphorylation (OXPHOS), mitochondrial complex I and complex IV were significantly decreased under ER stress conditions in INS1E-hIAPP-overexpressing cells compared to the control (Figure 4).

\subsection{The hIAPP Oligomerization/Expression and Signal Pathways under Oxidative Stress Conditions}

Second, we investigated hIAPP oligomerization/expression and signal pathways under oxidative stress in INS-1E cells. Oxidative stress is induced by serum deprivation, nitric oxide, or hydrogen peroxide treatments. Cell viability did not change in serum deprivation but significantly decreased in nitric oxide and hydrogen peroxide conditions (Figure 5). The pCMV-hIAPP-overexpressing cells pattern of amylin oligomerization/ expression under oxidative stress was different from that of ER stress. Amylin oligomerization/expression under oxidative stress showed one band of amylin oligomers of less than $15 \mathrm{kDa}$ in INS-1E cells. Under oxidative stress conditions (Figure 6), HIF1 $\alpha$, p-ERK, CHOP, Mn-SOD, catalase, and Bcl-2 were significantly reduced in the pCMV-hIAPPoverexpressing cells compared to the control. In contrast, p-mTOR, $\mathrm{Cu} / \mathrm{Zn}-\mathrm{SOD}$, and Bax were significantly increased (Figures 6 and 7). In mitochondrial OXPHOS, mitochondrial 
complex I and complex IV were significantly increased under oxidative stress conditions in pCMV-hIAPP-overexpressing INS-1E cells compared to the control (Figure 8).

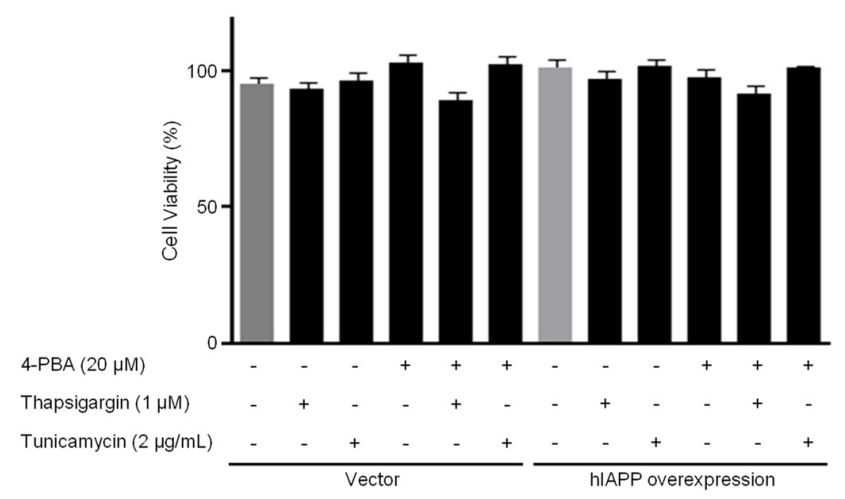

Figure 1. Cell viability in pCMV-Entry-expressing cells and INS1E-hIAPP-overexpressing cells under ER stress conditions. INS-1E cells were incubated in RPMI 1640 medium supplemented with $2 \%$ fetal bovine serum with/without thapsigargin $(1 \mu \mathrm{M})$ for $6 \mathrm{~h}$ or tunicamycin $(2 \mu \mathrm{g} / \mathrm{mL})$ for $16 \mathrm{~h}$ and/or with/without 4-PBA $(20 \mu \mathrm{M})$ at $37^{\circ} \mathrm{C}$ with $5 \% \mathrm{CO}_{2}$. Cell viability was analyzed by Cell Counting Kit-8. Values are presented as the mean $\pm \mathrm{SEM}$ of three experiments.
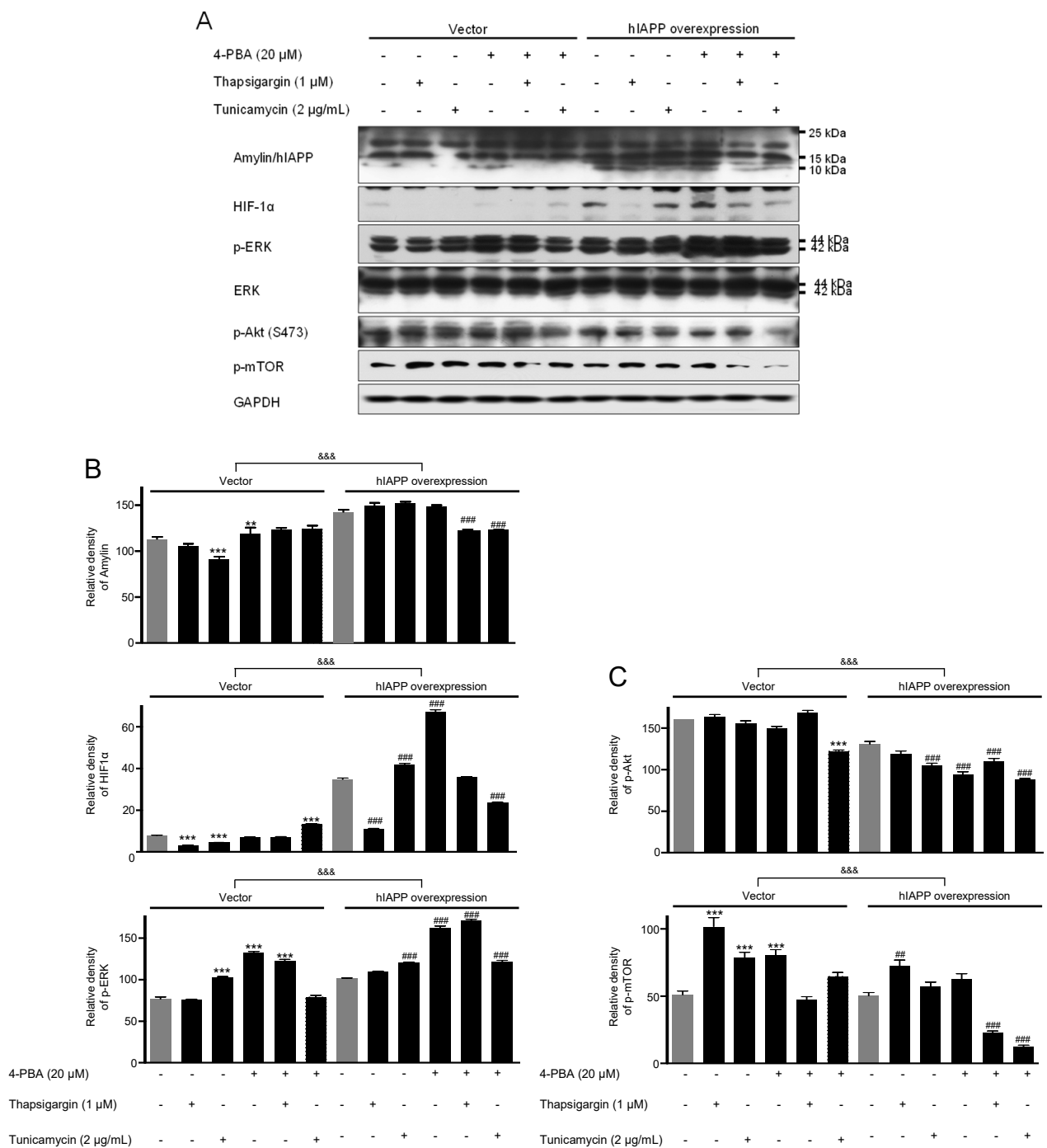

Figure 2. The expressions of amylin/hIAPP, HIF1 $\alpha$, p-ERK, p-Akt, and p-mTOR proteins in pCMVEntry-expressing cells and INS1E-hIAPP-overexpressing INS-1E cells under ER stress conditions. 
INS-1E cells were incubated in RPMI 1640 medium supplemented with $2 \%$ fetal bovine serum with/without thapsigargin $(1 \mu \mathrm{M})$ for $6 \mathrm{~h}$ or tunicamycin $(2 \mu \mathrm{g} / \mathrm{mL})$ for $16 \mathrm{~h}$ and $/$ or with/without 4-PBA $(20 \mu \mathrm{M})$ at $37^{\circ} \mathrm{C}$ with $5 \% \mathrm{CO}_{2}$. Amylin/hIAPP, HIF1 $\alpha$, p-ERK, p-Akt, and p-mTOR were then analyzed by Western blot (A). The relative amounts of Amylin/hIAPP, HIF1 $\alpha$, and p-ERK (B) and p-Akt, and p-mTOR (C) were quantified as described in Materials and Methods. Data represent the mean \pm SEM of three experiments. ${ }^{* *} p<0.01,{ }^{* * *} p<0.001$ vs. $2 \%$ FBS in pCMV-Entry-expressing cells; ${ }^{\# \#} p<0.01, \#$ \# $p 0.001$ vs. 2\% FBS in INS1E-hIAPP-overexpressing cells; \&\&\& $p<0.001$, pCMV-Entry-expressing cells vs. INS1E-hIAPP-overexpressing cells.
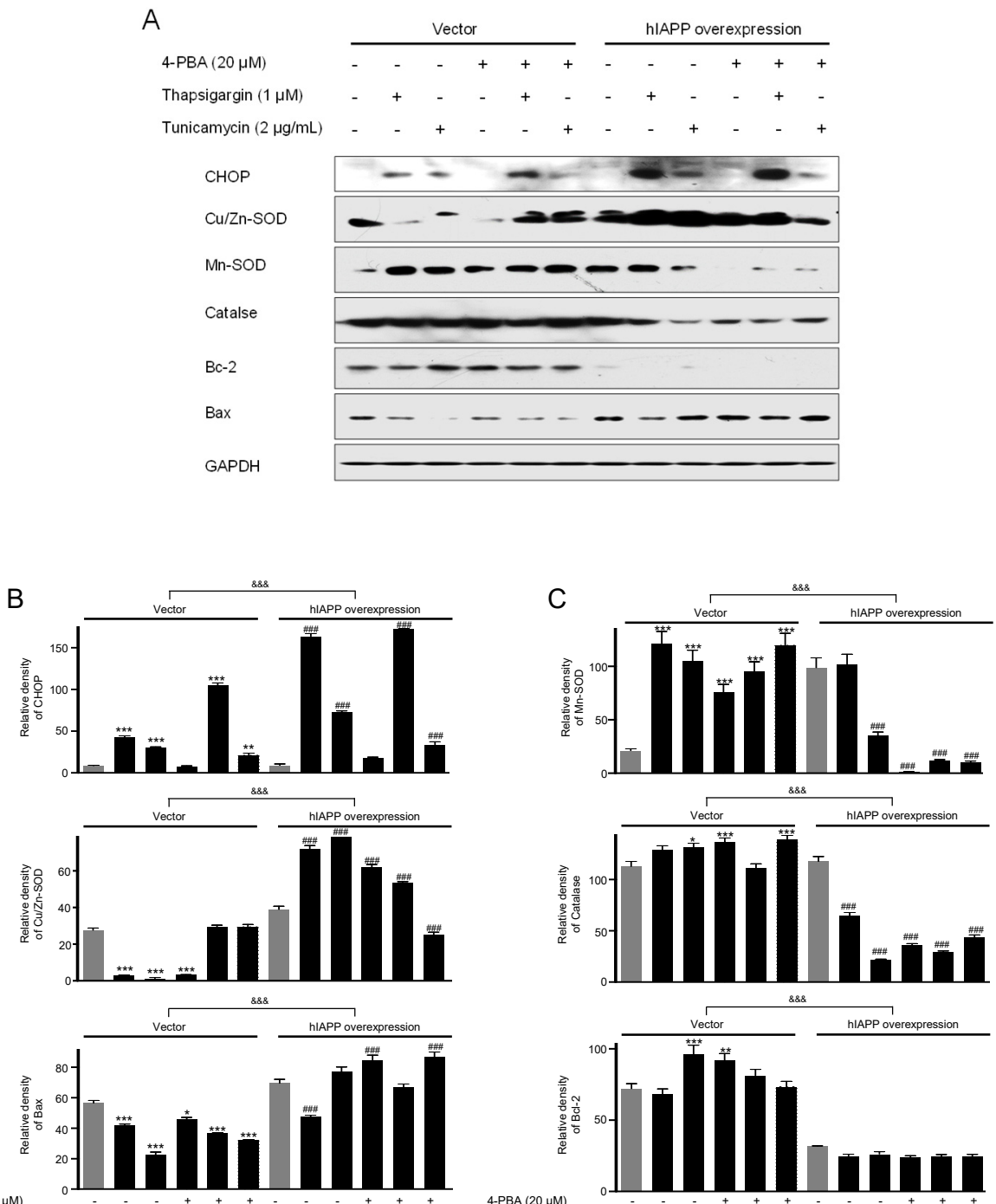

-PBA $(20 \mu \mathrm{M})$

$\mu \mathrm{M})$

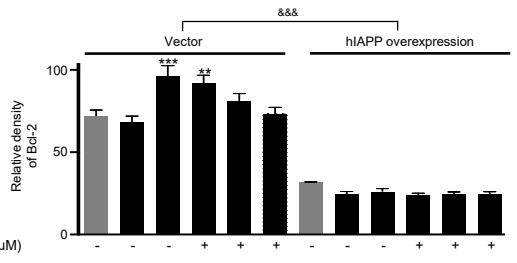

Figure 3. The expressions of $\mathrm{CHOP}, \mathrm{Cu} / \mathrm{Zn}-\mathrm{SOD}, \mathrm{Mn}-\mathrm{SOD}$, catalase, $\mathrm{Bcl}-2$, and Bax proteins in pCMVEntry-expressing cells and INS1E-hIAPP-overexpressing INS-1E cells under ER stress conditions. INS-1E cells were incubated in RPMI 1640 medium supplemented with $2 \%$ fetal bovine serum with/without thapsigargin $(1 \mu \mathrm{M})$ for $6 \mathrm{~h}$ or tunicamycin $(2 \mu \mathrm{g} / \mathrm{mL})$ for $16 \mathrm{~h}$ and $/$ or with/without 4-PBA $(20 \mu \mathrm{M})$ at $37{ }^{\circ} \mathrm{C}$ with $5 \% \mathrm{CO}_{2}$. CHOP, Cu/Zn-SOD, Mn-SOD, catalase, Bcl-2, and Bax were then analyzed by Western blot (A). The relative amounts of $\mathrm{CHOP}, \mathrm{Cu} / \mathrm{Zn}-\mathrm{SOD}$, and Bax (B) and Mn-SOD, catalase, and Bcl-2 (C) were quantified as described in Materials and Methods. Data represent the mean \pm SEM of three experiments. ${ }^{*} p<0.05,{ }^{* *} p<0.01,{ }^{* * *} p<0.001$ vs. $2 \%$ FBS in pCMV-Entry-expressing cells; ${ }^{\# \#} p<0.001$ vs. $2 \%$ FBS in INS1E-hIAPP-overexpressing cells; $\& \& \& p<0.001$, pCMV-Entry-expressing cells vs. INS1E-hIAPP-overexpressing cells. 
A

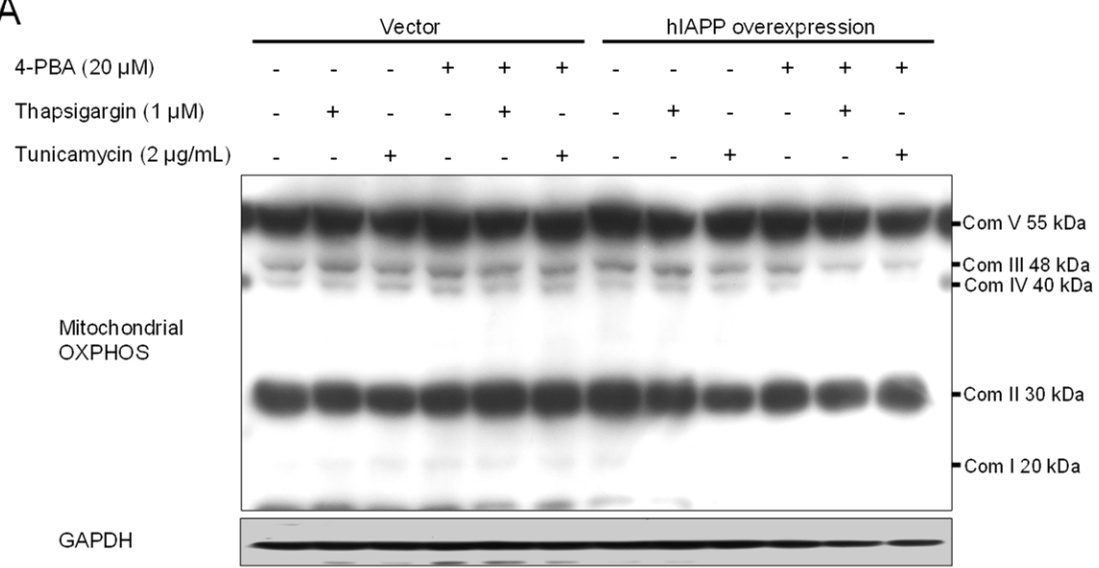

B
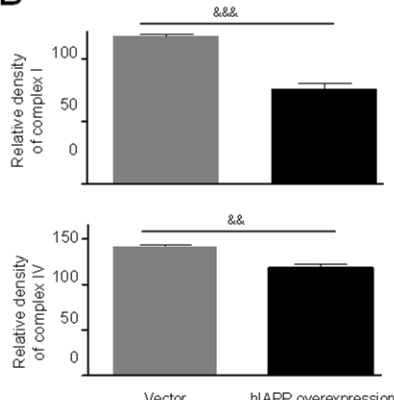

vect

Figure 4. The effect of mitochondrial complex I and complex IV of OXPHOS in pCMV-Entryexpressing cells and INS1E-hIAPP-overexpressing INS-1E cells under ER stress conditions. INS-1E cells were incubated in RPMI 1640 medium supplemented with $2 \%$ fetal bovine serum with/without thapsigargin $(1 \mu \mathrm{M})$ for $6 \mathrm{~h}$ or tunicamycin $(2 \mu \mathrm{g} / \mathrm{mL})$ for $16 \mathrm{~h}$ and / or with/without 4-PBA $(20 \mu \mathrm{M})$ at $37^{\circ} \mathrm{C}$ with $5 \% \mathrm{CO}_{2}$. Mitochondrial complex I and complex IV were then analyzed by Western blot (A). The relative amounts of mitochondrial complex I and complex IV (B) were quantified as described in Materials and Methods. Data represent the mean \pm SEM of three experiments. \&\& $p<0.01$ \&\&\& $p<0.001$, pCMV-Entry-expressing cells vs. INS1E-hIAPP-overexpressing cells.

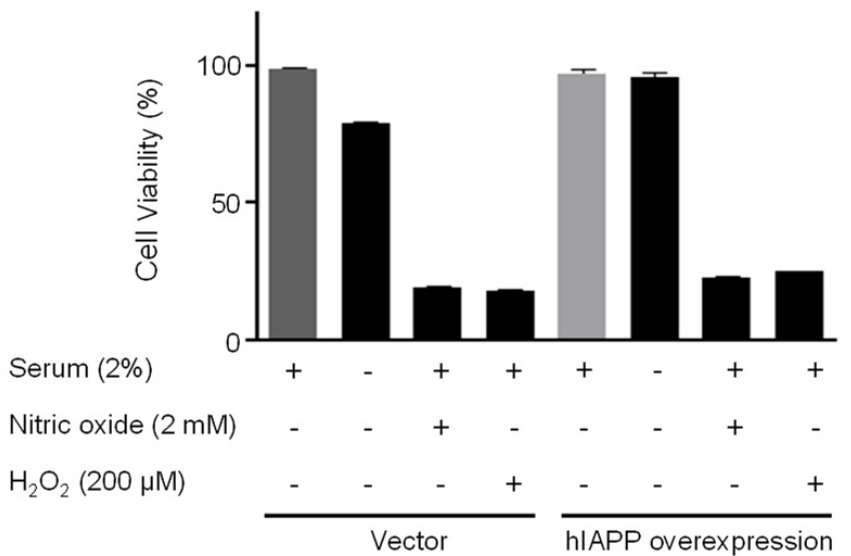

Figure 5. Cell viability in pCMV-Entry-expressing cells and INS1E-hIAPP-overexpressing cells under oxidative stress conditions. INS-1E cells were incubated in RPMI 1640 medium supplemented with/without $2 \%$ fetal bovine serum and/or nitric oxide $(2 \mathrm{mM})$ or hydrogen peroxide $(200 \mu \mathrm{M})$ for $24 \mathrm{~h}$ at $37^{\circ} \mathrm{C}$ with $5 \% \mathrm{CO}_{2}$. Cell viability was analyzed by Cell Counting Kit-8. Values are presented as the mean \pm SEM of three experiments. 


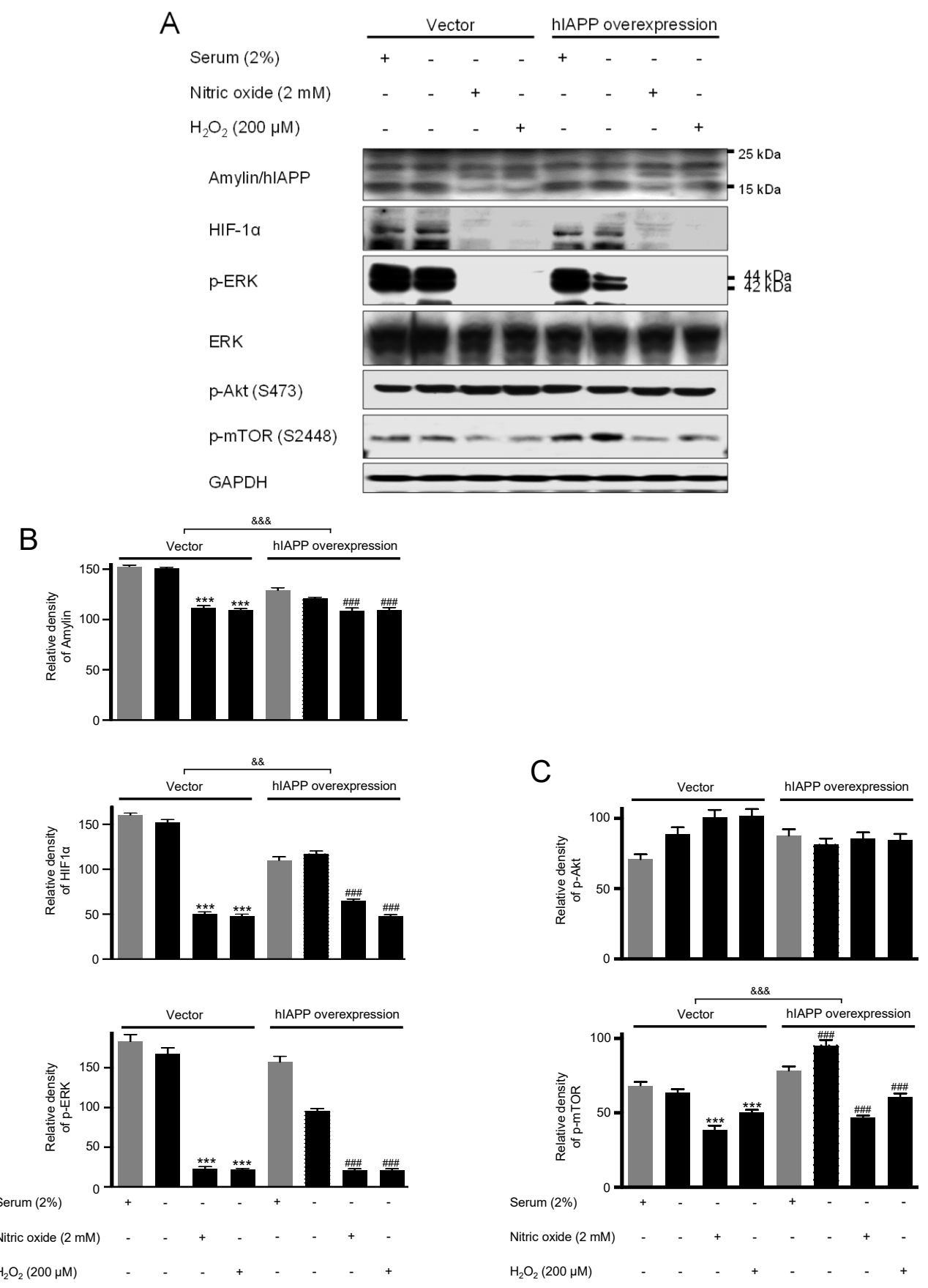

Figure 6. The expressions of amylin/hIAPP, HIF1 $\alpha$, p-ERK, p-Akt, and p-mTOR proteins in pCMVEntry-expressing cells and INS1E-hIAPP-overexpressing INS-1E cells under oxidative stress conditions. INS-1E cells were incubated in RPMI 1640 medium supplemented with/without $\%$ fetal bovine serum and/or nitric oxide $(2 \mathrm{mM})$ or hydrogen peroxide $(200 \mu \mathrm{M})$ for $24 \mathrm{~h}$ at $37^{\circ} \mathrm{C}$ with $5 \% \mathrm{CO}_{2}$. Amylin/hIAPP, HIF1 $\alpha$, p-ERK, p-Akt, and p-mTOR were then analyzed by Western blot (A). The relative amounts of Amylin/hIAPP, HIF1 $\alpha$, and p-ERK (B) and p-Akt, and p-mTOR (C) were quantified as described in Materials and Methods. Data represent the mean \pm SEM of three experiments. ${ }^{* * *} p<0.001$ vs. $2 \%$ FBS in pCMV-Entry-expressing cells; ${ }^{\# \#} p<0.001$ vs. $2 \%$ FBS in INS1E-hIAPP-overexpressing cells; \&\& $p<0.01$, \&\&\& $p<0.001$, pCMV-Entry-expressing cells vs. INS1E-hIAPP-overexpressing cells. 


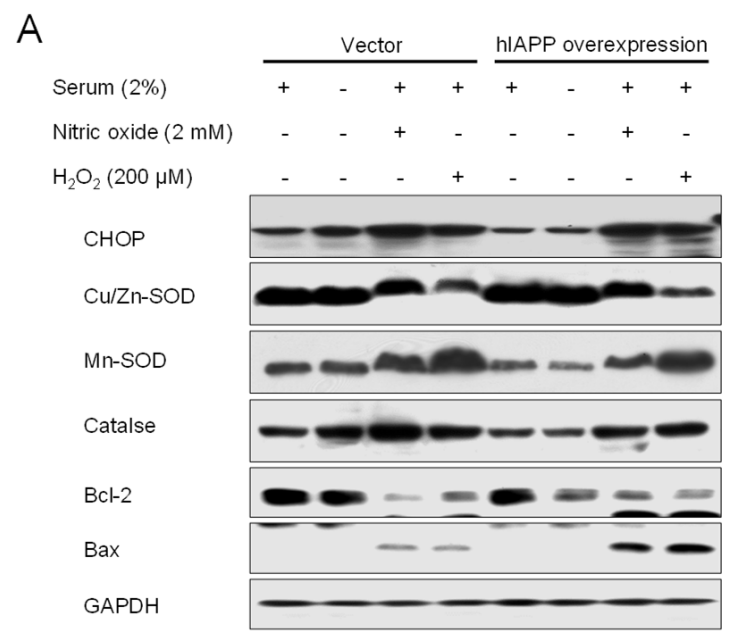

B
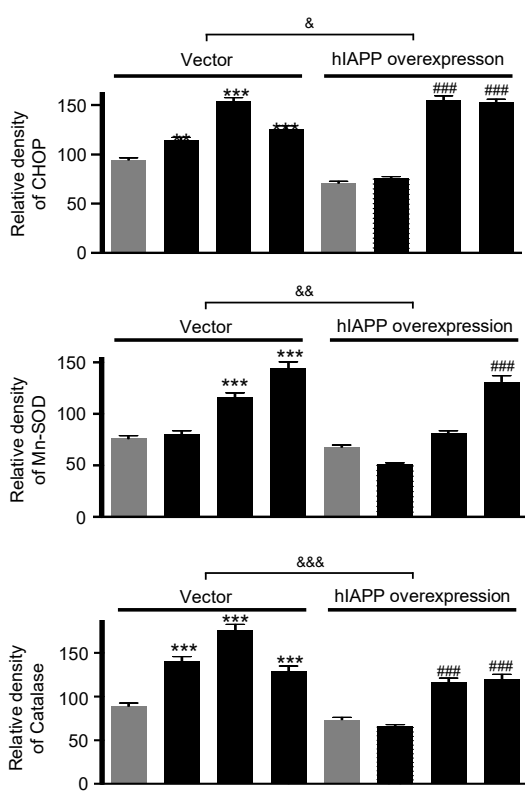

C
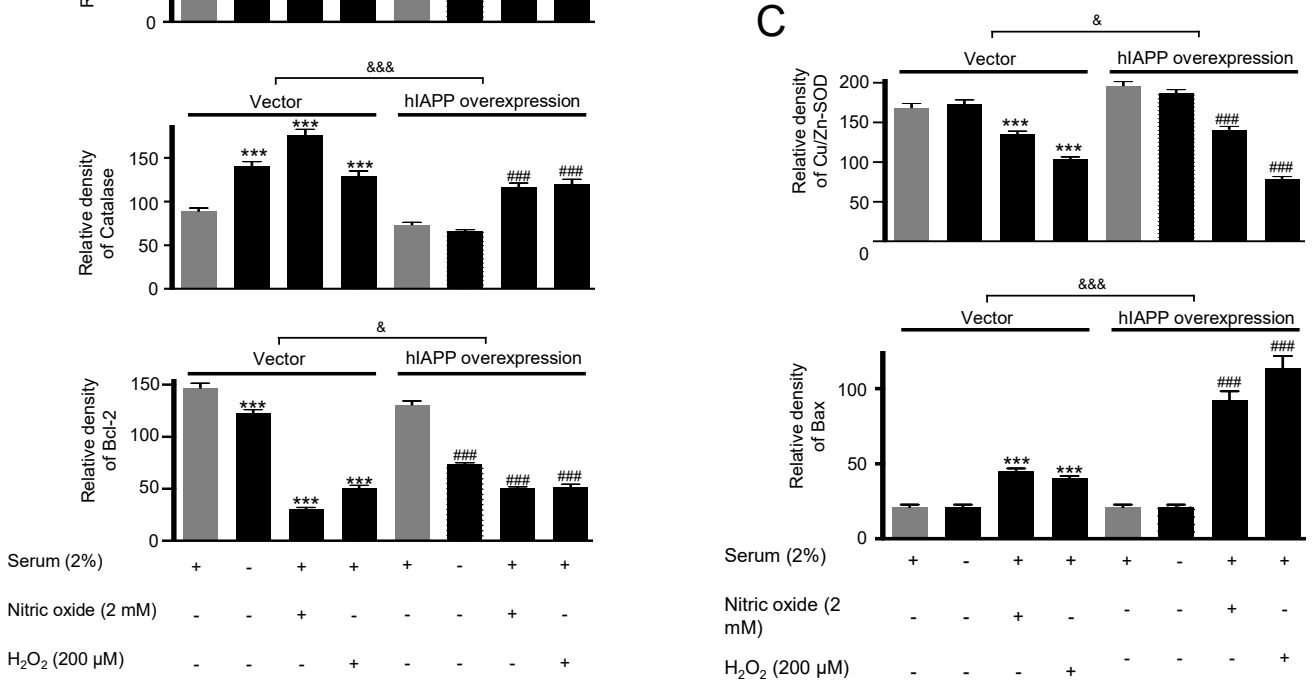

Figure 7. The expressions of $\mathrm{CHOP}, \mathrm{Cu} / \mathrm{Zn}-\mathrm{SOD}, \mathrm{Mn}-\mathrm{SOD}$, catalase, $\mathrm{Bcl}-2$, and Bax proteins in pCMV-Entry-expressing cells and INS1E-hIAPP-overexpressing INS-1E cells under oxidative stress conditions. INS-1E cells were incubated in RPMI 1640 medium supplemented with/without $2 \%$ fetal bovine serum and/or nitric oxide $(2 \mathrm{mM})$ or hydrogen peroxide $(200 \mu \mathrm{M})$ for $24 \mathrm{~h}$ at $37^{\circ} \mathrm{C}$ with $5 \%$ $\mathrm{CO}_{2}$. CHOP, $\mathrm{Cu} / \mathrm{Zn}-\mathrm{SOD}, \mathrm{Mn}-\mathrm{SOD}$, catalase, $\mathrm{Bcl}-2$, and Bax were then analyzed by Western blot (A). The relative amounts of CHOP, Mn-SOD, catalase, and Bcl-2 (B) and Cu/Zn-SOD, and Bax (C) were quantified as described in Materials and Methods. Data represent the mean $\pm \mathrm{SEM}$ of three experiments. ${ }^{* * *} p<0.001$ vs. $2 \%$ FBS in pCMV-Entry-expressing cells; $\#<0.001$ vs. $2 \%$ FBS in INS1E-hIAPP-overexpressing cells; \& $p<0.05$, \&\& $p<0.01$, \&\&\& $p<0.001$, pCMV-Entry-expressing cells vs. INS1E-hIAPP-overexpressing cells. 
A

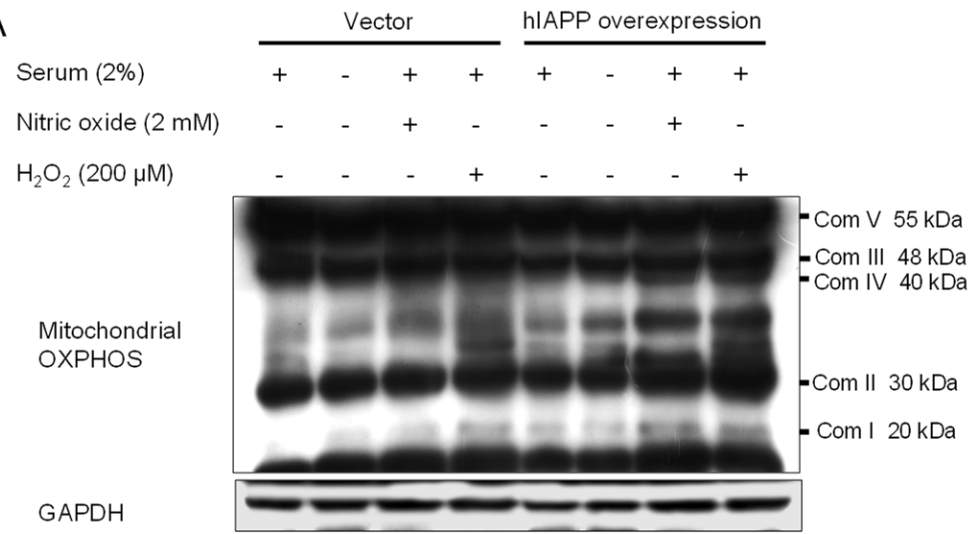

B
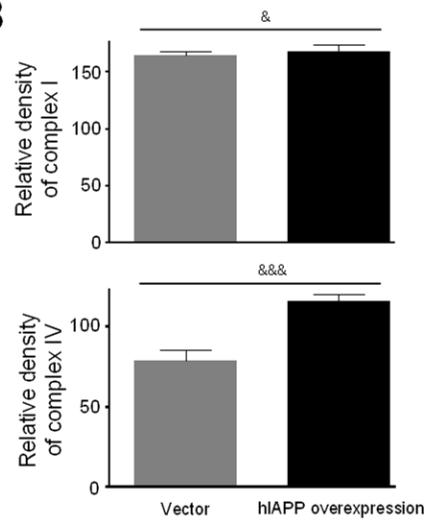

Figure 8. The effect of mitochondrial complex I and complex IV of OXPHOS in pCMV-Entryexpressing cells and INS1E-hIAPP-overexpressing INS-1E cells under oxidative stress conditions. INS-1E cells were incubated in RPMI 1640 medium supplemented with/without $2 \%$ fetal bovine serum and/or nitric oxide $(2 \mathrm{mM})$ or hydrogen peroxide $(200 \mu \mathrm{M})$ for $24 \mathrm{~h}$ at $37^{\circ} \mathrm{C}$ with $5 \% \mathrm{CO}_{2}$. Mitochondrial complex I and complex IV were then analyzed by Western blot (A). The relative amounts of mitochondrial complex I and complex IV (B) were quantified as described in Materials and Methods. Data represent the mean \pm SEM of three experiments. \& $p<0.05$, \&\&\& $p<0.001$, pCMV-Entry-expressing cells vs. INS1E-hIAPP-overexpressing cells.

\subsection{Comparing Amylin Oligomerization/Expression and Cell Signaling under ER Stress and Oxidative Stress Conditions}

Human amylin oligomerization/expression under ER stress showed three bands of amylin oligomers of less than $15 \mathrm{kDa}$ size in pCMV-hIAPP-overexpressing cells ER stress and one band under oxidative stress (Figures 1, 2, 5 and 6). HIF1 $\alpha$, p-ERK, and CHOP proteins were increased and decreased respectively under ER stress and oxidative stress, but $\mathrm{Cu} / \mathrm{Zn}-\mathrm{SOD}$, Mn-SOD, catalase, Bcl-2, Bax, and mitochondrial complex I/IV proteins were reversely expressed (Figures 2-4 and 6-8). These results suggest that ER stress has a more significant effect on intracellular amylin oligomerization than oxidative stress, and therefore has a significant contribution in inducing human pancreatic $\beta$-cell dysfunction and subsequent T2D and that ER stress and oxidative stress influence intracellular signal pathways differently, consequently leading to varied intracellular stress effects.

\section{Discussion}

Wong et al. [19] demonstrated that overexpression of hIAPP in INS-1 cells formed three oligomers between 4 and $8 \mathrm{kDa}$ in size. Kim et al. [20] showed that hIAPP-transfected INS-1 cells expressed three oligomers of less than $17 \mathrm{kDa}$ size under autophagy inhibition conditions, including inhibition by 3-methyladenine and bafilomycin. These results suggest that autophagy can eliminate amyloidogenic hIAPP and that autophagy deficiency con- 
tributes to the pathogenesis of human T2D. Burillo et al. [21] reported that overexpressing hIAPP in INS-1E cells accumulated one amylin protein of approximately $16 \mathrm{kDa}$ under high glucose conditions, suggesting that this band corresponds to the aggregation of $16 \mathrm{kDa}$ amylin protein as a tetramer. Chatterjee Bhowmick and Jeremic [22] revealed that human pancreatic islets induced three amylin oligomers of approximately $6 \mathrm{kDa}$ in size under high glucose with/without proteasomal inhibitor, indicating a relation between hIAPP turnover and proteasome function in human islet $\beta$-cells. Chatterjee Bhowmick et al. [23] identified three amylin oligomers of approximately $6 \mathrm{kDa}$ in size under high glucose $(20 \mathrm{mM})$ media for 4 days and $0.5 \mu \mathrm{M}$ thapsigargin (TG) for $24 \mathrm{~h}$ in human islets. They suggested that hIAPP biosynthesis is associated with ER-stressed human islet cells. ER stress may increase intracellular hIAPP levels by inhibiting the processing and/or secretion of amylin. Similarly, the present study results showed three bands of amylin oligomers of less than $15 \mathrm{kDa}$ in size in INS-1E cells under ER stress and one oligomer under oxidative stress, suggesting that ER stress has a more significant effect on intracellular amylin oligomerization than oxidative stress. Additionally, this indicated that oligomerization differed depending on the cell-applied conditions and the amylin antibody used in the above studies. These results were obtained in vitro, but it is difficult to confirm the formation of amylin in vivo. A similar mechanism could facilitate the access of aggregated human amylin protein to the extra-pancreatic regions. This could be a plausible explanation for human amylin-induced human pancreatic $\beta$-cell dysfunction and subsequent T2D and Alzheimer's disease [24,25].

The association between hIAPP-induced cytotoxicity and HIF1 $\alpha$ activation is vital in the pancreatic $\beta$-cells. The activation of HIF1 $\alpha$ and 6-phosphofructo-2-kinase/fructose 2,6 biphosphatase-3 (PFKFB3) metabolic pathway protects against hIAPP-induced $\beta$-cell apoptosis associated with T2D [26] and cytokine-induced $\beta$-cell death related to T1D [27]. Changes in the mitochondrial function and metabolism by hIAPP toxicity determine the role of $\beta$-cells in T2D $[26,28,29]$. hIAPP-induced $\beta$-cells toxicity is inhibited by protective metabolism induced by the HIF1 $\alpha$ /PFKFB3 metabolic stress pathway, which slow cellular metabolism without blocking cellular dysfunction. That is, suppression of HIF1 $\alpha$ activation enhances hIAPP-induced $\beta$-cytotoxicity. Wong et al. [19] showed that hIAPP aggregation in adenoviral hIAPP transduced INS-1E cells and human islet $\beta$-cells triggers mitochondrial apoptosis and blocks the release of cytochrome $\mathrm{c}$ or pro-apoptotic proteins Bax and Bak. The hIAPP aggregates were demonstrated to enhance the survival of $\beta$ cells. Rivera et al. [30] reported that hIAPP aggregates impair the autophagy/lysosomal degradation pathway in pancreatic $\beta$ cells, indicating that enhanced autophagy protects $\beta$-cells from hIAPP-induced apoptosis. However, overexpression of hIAPP in INS-1E cells induces MTORC1 activation and mitophagy inhibition [21,31]. These findings suggest that hIAPP aggregates can indirectly activate Bax/Bak, resulting in mitochondria dysfunction, oxidative stress, and ER stress. The fiber formation of hIAPP and amyloid aggregation causes extensive oxidative stress on pancreatic tissue. The binding of copper ions to hIAPP can produce ROS [32], resulting in a partial reduction of the $\beta$-cell mass. In practice, various cells components are transformed by ROS, acting as biomarkers for T2D and prediabetic stages [33,34]. In the present study, HIF1 $\alpha$ in hIAPP-overexpressing cells significantly increased under ER stress, but HIF1 $\alpha$ in INS-1E and hIAPP-overexpressing INS-1E cells significantly decreased under oxidative stress. Phospho-mTOR, Bcl-2, Bax, $\mathrm{Mn}-\mathrm{SOD}, \mathrm{Cu} / \mathrm{Zn}-\mathrm{SOD}$, catalase, and mitochondrial complex I/IV related to mitochondrial function were investigated. Protein expressions of phospho-mTOR and mitochondrial complex I/IV between oxidative stress and ER stress were opposite, while the levels of $\mathrm{Bcl}-2$, Bax, $\mathrm{Mn}-\mathrm{SOD}, \mathrm{Cu} / \mathrm{Zn}-\mathrm{SOD}$, and catalase proteins between oxidative stress and ER stress were similar. ER stress and serum deprivation did not influence the INS -1E cell viability, but nitric oxide and hydrogen peroxide conditions induced cell death.

So far, various studies on the role of mitochondria in human diseases have been conducted with significant progress. Although mitochondria are central to energy metabolism, they play a critical role in apoptosis [35,36] and cell proliferation [37]. Mitochondria are also major organelles regulating calcium signaling as a secondary messenger [38,39]. 
The OXPHOS system produces mitochondrial ATP [40]. OXPHOS couples two sets of reactions, the phosphorylation of ADP and electron transfer through a chain of oxidoreductase reactions. Most eukaryotes consist of 5 enzyme complexes embedded in the mitochondrial inner membrane: complex I (NADH:ubiquinone oxidoreductase), complex II (Succinate:ubiquinone oxidoreductase), complex III (cytochrome c oxidoreductase or cytochrome bc1 complex), complex IV (cytochrome c oxidase), and complex V (ATP synthase). Complex I is the multimeric enzyme complex of the mitochondrial respiratory chain, which is responsible for electron transport and generating a proton gradient across the mitochondrial inner membrane to drive ATP production. Complex I dysfunction is the most common OXPHOS disorder in humans, and defects in the complex I assembly process are common [41,42]. In particular, complex I regulate reactive oxygen species (ROS), which are essential molecules in various signaling pathways, including apoptosis. The final enzyme complex IV reduces $\mathrm{O}_{2}$ to $\mathrm{H}_{2} \mathrm{O}$ in the electron transfer chain using the delivered electrons [43]. Through the pathway by complexes I, III, and IV, five protons per electron are pumped from the mitochondrial matrix into the intermembrane space, creating a membrane potential. Next, the transmembrane electrochemical potential promotes the conformational change of Complex V, resulting in the generation of ATP [44].

One component of ER stress-mediated apoptosis pathway is C/EBP homologous protein (CHOP) which is associated with cell death by growth arrest and DNA damage. Thus, CHOP as an ER stress-mediated apoptotic factor plays a significant role in the pathogenesis of diabetes, ischemia, and neurodegenerative diseases [45]. CHOP-deleted mice showed reduced apoptosis in response to ER stress [46-48]. On the other hand, $\mathrm{CHOP}$ overexpression reduces $\mathrm{Bcl}-2$ protein and translocates Bax protein from the cytosol to the mitochondria [49,50]. Therefore, eventually, CHOP-mediated death signals affect the mitochondria as an essential factor in the path of cell death. The high expression levels of hIAPP in INS- 1 cells and human IAPP transgenic rats induce ER stress-mediated $\beta$ cell apoptosis and increase CHOP expression [51-53], suggesting that oligomerization by hIAPP can be toxic and cause ER stress-induced apoptosis. ER stress plays a causative role in beta-cell dysfunction in overexpressing hIAPP [54]. hAIPP transgenic and nontransgenic mouse islets induce oxidative stress, and amyloid formation mediates $\beta$-cell apoptosis [55,56]. In the present study, ER stress and oxidative stress influenced the CHOP protein levels in hIAPP-overexpressing cells with the change of Bcl-2 and Bax protein levels.

So far, very few studies have discussed ERK and Akt's activation under ER stress and oxidative stress conditions by hIAPP overexpression. In this study, the ER stress caused by hIAPP overexpression did not affect cell survival and seemed to involve the Akt/mTOR pathway. On the other hand, oxidative stress conditions reduced cell survival without the effect of hIAPP overexpression, which was associated with phospho-ERK reduction. hIAPP overexpression induces $\beta$-cell apoptosis by regulating Fak and Akt phosphorylation in the $\beta$-cells [57]. Notably, Cyclin-dependent kinase 5 (CDK5) is especially required for neuronal survival by activating ERK and PI3K/Akt pathways [58,59]. The loss of CDK5 in both INS 832/13 cells and primary $\beta$-cells resulted in an attenuation of PI3K/Akt survival pathway and increased $\beta$-cell apoptosis.

\section{Materials and Methods}

\subsection{Cell Culture and Induction of ER Stress and Oxidative Stress}

The INS-1E cells were cultured in RPMI 1640 medium (Invitrogen, Carlsbad, CA, USA) containing $11 \mathrm{mM}$ glucose supplemented with $10 \mathrm{mM}$ HEPES ( $\mathrm{pH} 7.3$ ), 10\% heatinactivated fetal bovine serum (FBS; Invitrogen), $50 \mu \mathrm{M} \beta$-mercaptoethanol, $1 \mathrm{mM}$ sodium pyruvate, $50 \mu \mathrm{g} / \mathrm{mL}$ penicillin, and $100 \mu \mathrm{g} / \mathrm{mL}$ streptomycin at $37^{\circ} \mathrm{C}$ with $5 \% \mathrm{CO}_{2}$ in a humidified incubator. ER stresses are induced by thapsigargin $(1 \mu \mathrm{M}$; Calbiochem, San Diego, MO, USA) for $6 \mathrm{~h}$ or tunicamycin $(2 \mu \mathrm{g} / \mathrm{mL}$; Calbiochem $)$ for $16 \mathrm{~h}$ treatments with/without 4-phenylbutyric acid (4-PBA, $20 \mu \mathrm{M}$; Santa Cruz Biotechnology, Santa Cruz, CA, USA). Oxidative stresses are induced by serum deprivation, nitric oxide (2 mM; 
Santa Cruz Biotechnology), or hydrogen peroxide (200 $\mu$ M; Santa Cruz Biotechnology) for $24 \mathrm{~h}$ treatments.

\subsection{INS-1E Stable Cell Line by Overexpressing hIAPP}

CMV6-Entry (control) and pCMV6-hIAPP vectors were purchased from OriGene Technologies Inc. (Rockville, MD, USA). These vectors were transfected individually into INS-1E cells Opti-MEM ${ }^{\circledR}$ (Gibco BRL, CA, USA). Stably transfected cells were selected in $200 \mu \mathrm{g} / \mathrm{mL}$ G418 containing growth media and thus pCMV-hIAPP-overexpressing cells and pCMV-Entry-expressing cells (control).

\subsection{Cell Viability Assay}

According to the manufacturer's protocol, cell viability was determined using a Cell Counting Kit-8 (Dojindo Molecular Technologies, Inc.). Cells were plated in 96-well plates (Corning, Inc., Corning, NY, USA) at $5 \times 10^{3} /$ well density. The cells were treated with the $10 \mu \mathrm{L}$ kit solution, incubated for $30 \mathrm{~min}$, and their absorbance was measured at $450 \mathrm{~nm}$. Percent viability was calculated as follow: Cell Viability $(\%)=[($ Total absorbanceBackground absorbance)/Control absorbance] $\times 100$.

\subsection{Western Blot Analysis}

Cell extracts were lysed in $20 \mathrm{mM}$ Tris-HCl buffer (pH 7.4) containing $0.1 \mathrm{mM}$ PMSF, and 1:100 protease inhibitor cocktail (Sigma, St Louis, MI, USA) at $4{ }^{\circ} \mathrm{C}$. Protein concentrations were determined using the BCA assay (Sigma). Proteins $(40 \mu \mathrm{g})$ resolved by $10 \%$ Gradi-Gel II gradient PAGE (ELPIS-Biotech, Daejeon, Korea). After gel electrophoresis, the protein was transferred to a polyvinylidene difluoride (PVDF) membrane. The membrane was incubated with antibodies. The amylin antibody (catalog no. LS-C352341; 1:1000) was provided from LifeSpan BioSciences, Phospho-ERK (catalog no. sc-7380; 1:500), ERK (catalog no. sc-93; 1:500), Cu/Zn-SOD (catalog no. sc-271014; 1:500), Mn-SOD (catalog no. sc-137254; 1:500), C/EBP-homologous protein (CHOP; catalog no. sc-575; 1:500) Bcl-2 (cata$\log$ no. sc-7382; 1:500), Bax (catalog no. sc-7480; 1:500), and GAPDH (catalog no. sc-25778; 1:500) obtained from Santa Cruz Biotechnology (Santa Cruz). Hypoxia-inducible factor (HIF)-1 $\alpha$ (catalog no. 14179, 1:1000) p-Akt (catalog no. 4051; 1:1000), p-mTOR (catalog no. $2971 ; 1: 1000$ ), and catalase (catalog no. 12980; 1:1000) were provided by Cell Signaling Technology, Inc. (Danvers, MA, USA) Subsequently, the membranes were incubated with anti-mouse IgG (catalog no. 7076; 1:1000; Cell Signaling Technology, Inc.) or anti-rabbit IgG secondary antibodies conjugated to HRP (catalog no. 7074; 1:1000; Cell Signaling Technology, Inc.) for $1 \mathrm{~h}$ in room temperature. Protein bands were detected with chemiluminescent substrate (Thermo Fisher Scientific, Inc., Waltham, MA, USA) and then measured using ImageJ software (version 1.37; National Institute of Health).

\subsection{Statistical Analysis}

Significant analyses were determined by using ANOVA followed by Tukey's test for multiple comparisons with the Prism Graph Pad v4.0 (Graph Pad Software, San Diego, CA, USA). Values are expressed as means \pm SEM of at least three separate experiments. $p$ values $<0.05$ were considered statistically significant.

\section{Conclusions}

We tried to compare human amylin oligomerization/expression and signal transduction under ER stress and oxidative stress. Human amylin undergoes protein oligomerization under ER stress in hIAPP-overexpressing INS-1E cells. ER stress has a more significant effect on intracellular amylin oligomerization than oxidative stress. ER stress and oxidative stress influence intracellular signal pathways differently, consequently leading to varied effects of intracellular stress. Therefore, human amylin overexpression with ER stress significantly contributes to inducing human pancreatic $\beta$-cell dysfunction and subsequent T2D. 
Author Contributions: Conceptualization, methodology, validation, formal analysis, investigation, resources, data curation, writing-original draft preparation, writing-review and editing, Y.-M.Y. and S.S.J.; Funding acquisition, supervision, project administration, Y.-M.Y. All authors have read and agreed to the published version of the manuscript.

Funding: This research was supported by the Basic Science Research Program through the National Research Foundation of Korea (NRF) funded by the Ministry of Education (2020R1I1A1A01060627).

Data Availability Statement: The data presented in this study are available on request from the corresponding author.

Conflicts of Interest: The authors declare no conflict of interest.

\section{References}

1. Akter, R.; Bower, R.L.; Abedini, A.; Schmidt, A.M.; Hay, D.L.; Raleigh, D.P. Amyloidogenicity, Cytotoxicity, and Receptor Activity of Bovine Amylin: Implications for Xenobiotic Transplantation and the Design of Nontoxic Amylin Variants. ACS Chem. Biol. 2018, 13, 2747-2757. [CrossRef]

2. Milardi, D.; Gazit, E.; Radford, S.E.; Xu, Y.; Gallardo, R.U.; Caflisch, A.; Westermark, G.T.; Westermark, P.; Rosa, C.; Ramamoorthy, A. Proteostasis of Islet Amyloid Polypeptide: A Molecular Perspective of Risk Factors and Protective Strategies for Type II Diabetes. Chem. Rev. 2021, 121, 1845-1893. [CrossRef] [PubMed]

3. Young, L.M.; Cao, P.; Raleigh, D.P.; Ashcroft, A.E.; Radford, S.E. Ion mobility spectrometry-mass spectrometry defines the oligomeric intermediates in amylin amyloid formation and the mode of action of inhibitors. J. Am. Chem. Soc. 2014, 136, 660-670. [CrossRef] [PubMed]

4. Westermark, P.; Engström, U.; Johnson, K.H.; Westermark, G.T.; Betsholtz, C. Islet amyloid polypeptide: Pinpointing amino acid residues linked to amyloid fibril formation. Proc. Natl. Acad. Sci. USA 1990, 87, 5036-5040. [CrossRef] [PubMed]

5. Betsholtz, C.; Christmanson, L.; Engström, U.; Rorsman, F.; Jordan, K.; O’Brien, T.D.; Murtaugh, M.; Johnson, K.H.; Westermark, P. Structure of cat islet amyloid polypeptide and identification of amino acid residues of potential significance for islet amyloid formation. Diabetes 1990, 39, 118-122. [CrossRef]

6. Bemporad, F.; Calloni, G.; Campioni, S.; Plakoutsi, G.; Taddei, N.; Chiti, F. Sequence and structural determinants of amyloid fibril formation. Acc. Chem. Res. 2006, 39, 620-627. [CrossRef]

7. Lee, K.H.; Noh, D.; Zhyvoloup, A.; Raleigh, D. Analysis of Prairie Vole Amylin Reveals the Importance of the N-Terminus and Residue 22 in Amyloidogenicity and Cytotoxicity. Biochemistry 2020, 59, 471-478. [CrossRef]

8. Lee, K.H.; Zhyvoloup, A.; Raleigh, D. Amyloidogenicity and cytotoxicity of des-Lys-1 human amylin provides insight into amylin self-assembly and highlights the difficulties of defining amyloidogenicity. Protein Eng. Des. Sel. 2019, 32, 87-93. [CrossRef]

9. Ridgway, Z.; Lee, K.H.; Zhyvoloup, A.; Wong, A.; Eldrid, C.; Hannaberry, E.; Thalassinos, K.; Abedini, A.; Raleigh, D.P. Analysis of Baboon IAPP Provides Insight into Amyloidogenicity and Cytotoxicity of Human IAPP. Biophys. J. 2020, 118, $1142-1151$. [CrossRef]

10. Nguyen, P.T.; Zottig, X.; Sebastiao, M.; Arnold, A.A.; Marcotte, I.; Bourgault, S. Identification of transmissible proteotoxic oligomer-like fibrils that expand conformational diversity of amyloid assemblies. Commun. Biol. 2021, 4, 939. [CrossRef] [PubMed]

11. Lorenzo, A.; Razzaboni, B.; Weir, G.C.; Yankner, B.A. Pancreatic islet cell toxicity of amylin associated with type-2 diabetes mellitus. Nature 1994, 368, 756-760. [CrossRef] [PubMed]

12. Szegezdi, E.; Logue, S.E.; Gorman, A.M.; Samali, A. Mediators of endoplasmic reticulum stress-induced apoptosis. EMBO Rep. 2006, 7, 880-885. [CrossRef] [PubMed]

13. Marchetti, P.; Bugliani, M.; Lupi, R.; Marselli, L.; Masini, M.; Boggi, U.; Filipponi, F.; Weir, G.C.; Eizirik, D.L.; Cnop, M. The endoplasmic reticulum in pancreatic beta cells of type 2 diabetes patients. Diabetologia 2007, 50, 2486-2494. [CrossRef]

14. Abedini, A.; Schmidt, A.M. Mechanisms of islet amyloidosis toxicity in type 2 diabetes. FEBS Lett. 2013, 587, 1119-1127. [CrossRef]

15. Raleigh, D.; Zhang, X.; Hastoy, B.; Clark, A. The $\beta$-cell assassin: IAPP cytotoxicity. J. Mol. Endocrinol. 2017, 59, R121-R140. [CrossRef]

16. Casas, S.; Gomis, R.; Gribble, F.M.; Altirriba, J.; Knuutila, S.; Novials, A. Impairment of the ubiquitin-proteasome pathway is a downstream endoplasmic reticulum stress response induced by extracellular human islet amyloid polypeptide and contributes to pancreatic beta-cell apoptosis. Diabetes 2007, 56, 2284-2294. [CrossRef] [PubMed]

17. Haataja, L.; Gurlo, T.; Huang, C.J.; Butler, P.C. Islet amyloid in type 2 diabetes, and the toxic oligomer hypothesis. Endocr. Rev. 2008, 29, 303-316. [CrossRef] [PubMed]

18. Soty, M.; Visa, M.; Soriano, S.; del Carmen Carmona, M.; Nadal, Á.; Novials, A. Involvement of ATP-sensitive potassium (K(ATP)) channels in the loss of beta-cell function induced by human islet amyloid polypeptide. J. Biol. Chem. 2011, 286, 40857-40866. [CrossRef] [PubMed]

19. Wong, H.Y.; Hui, Q.; Hao, Z.; Warnock, G.L.; Woo, M.; Luciani, D.S.; Marzban, L. The role of mitochondrial apoptotic pathway in islet amyloid-induced $\beta$-cell death. Mol. Cell. Endocrinol. 2021, 537, 111424. [CrossRef] 
20. Kim, J.; Cheon, H.; Jeong, Y.T.; Quan, W.; Kim, K.H.; Cho, J.M.; Lim, Y.M.; Oh, S.H.; Jin, S.M.; Kim, J.H.; et al. Amyloidogenic peptide oligomer accumulation in autophagy-deficient $\beta$ cells induces diabetes. J. Clin. Investig. 2014, 124, 3311-3324. [CrossRef]

21. Burillo, J.; Fernández-Rhodes, M.; Piquero, M.; López-Alvarado, P.; Menéndez, J.C.; Jiménez, B.; González-Blanco, C.; Marqués, P.; Guillén, C.; Benito, M. Human amylin aggregates release within exosomes as a protective mechanism in pancreatic $\beta$ cells: Pancreatic $\beta$-hippocampal cell communication. Biochim. Biophys. Acta Mol. Cell Res. 2021, 1868, 118971. [CrossRef]

22. Chatterjee Bhowmick, D.; Jeremic, A. Functional proteasome complex is required for turnover of islet amyloid polypeptide in pancreatic $\beta$-cells. J. Biol. Chem. 2018, 293, 14210-14223. [CrossRef]

23. Chatterjee Bhowmick, D.; Burnett, L.; Kudaibergenova, Z.; Jeremic, A.M. FoxA2 and RNA Pol II mediate human islet amyloid polypeptide turnover in ER-stressed pancreatic $\beta$-cells. Biochem. J. 2021, 478, 1261-1282. [CrossRef]

24. Zhang, Y.; Song, W. Islet amyloid polypeptide: Another key molecule in Alzheimer's pathogenesis? Prog. Neurobiol. 2017, 153, 100-120. [CrossRef] [PubMed]

25. Biessels, G.J.; Despa, F. Cognitive decline and dementia in diabetes mellitus: Mechanisms and clinical implications. Nat. Rev. Endocrinol. 2018, 14, 591-604. [CrossRef] [PubMed]

26. Montemurro, C.; Nomoto, H.; Pei, L.; Parekh, V.S.; Vongbunyong, K.E.; Vadrevu, S.; Gurlo, T.; Butler, A.E.; Subramaniam, R.; Ritou, E.; et al. IAPP toxicity activates HIF1 $\alpha$ /PFKFB3 signaling delaying $\beta$-cell loss at the expense of $\beta$-cell function. Nat. Commun. 2019, 10, 2679. [CrossRef] [PubMed]

27. Nomoto, H.; Pei, L.; Montemurro, C.; Rosenberger, M.; Furterer, A.; Coppola, G.; Nadel, B.; Pellegrini, M.; Gurlo, T.; Butler, P.C.; et al. Activation of the HIF1 $\alpha$ /PFKFB3 stress response pathway in beta cells in type 1 diabetes. Diabetologia 2020, 63, 149-161. [CrossRef]

28. Anello, M.; Lupi, R.; Spampinato, D.; Piro, S.; Masini, M.; Boggi, U.; Del Prato, S.; Rabuazzo, A.M.; Purrello, F.; Marchetti, P. Functional and morphological alterations of mitochondria in pancreatic beta cells from type 2 diabetic patients. Diabetologia 2005, 48, 282-289. [CrossRef]

29. Puri, S.; Cano, D.A.; Hebrok, M. A role for von Hippel-Lindau protein in pancreatic beta-cell function. Diabetes $2009,58,433-441$. [CrossRef]

30. Rivera, J.F.; Gurlo, T.; Daval, M.; Huang, C.J.; Matveyenko, A.V.; Butler, P.C.; Costes, S. Human-IAPP disrupts the autophagy/lysosomal pathway in pancreatic $\beta$-cells: Protective role of p62-positive cytoplasmic inclusions. Cell Death Differ. 2011, 18, 415-426. [CrossRef]

31. Hernández, M.G.; Aguilar, A.G.; Burillo, J.; Oca, R.G.; Manca, M.A.; Novials, A.; Alcarraz-Vizan, G.; Guillén, C.; Benito, M. Pancreatic $\beta$ cells overexpressing hIAPP impaired mitophagy and unbalanced mitochondrial dynamics. Cell Death Dis. 2018, 9, 481. [CrossRef]

32. Dong, X.; Svantesson, T.; Sholts, S.B.; Wallin, C.; Jarvet, J.; Gräslund, A.; Wärmländer, S.K.T.S. Copper ions induce dityrosinelinked dimers in human but not in murine islet amyloid polypeptide (IAPP/amylin). Biochem. Biophys. Res. Commun. 2019, 510, 520-524. [CrossRef]

33. Fang, M.; Yu, C.; Chen, S.; Xiong, W.; Li, X.; Zeng, R.; Zhuang, J.; Fan, R. Identification of Novel Clinically Relevant Variants in 70 Southern Chinese patients with Thoracic Aortic Aneurysm and Dissection by Next-generation Sequencing. Sci. Rep. 2017, 7, 10035. [CrossRef]

34. Chiu, C.J.; Rabbani, N.; Rowan, S.; Chang, M.L.; Sawyer, S.; Hu, F.B.; Willett, W.; Thornalley, P.J.; Anwar, A.; Bar, L.; et al. Studies of advanced glycation end products and oxidation biomarkers for type 2 diabetes. Biofactors 2018, 44, 281-288. [CrossRef]

35. Kroemer, G.; Reed, J.C. Mitochondrial control of cell death. Nat. Med. 2000, 6, 513-519. [CrossRef]

36. Wang, X. The expanding role of mitochondria in apoptosis. Genes Dev. 2001, 15, 2922-2933. [PubMed]

37. Rustin, P. Mitochondria, from cell death to proliferation. Nat. Genet. 2002, 30, 352-353. [CrossRef] [PubMed]

38. Babcock, D.F.; Hille, B. Mitochondrial oversight of cellular $\mathrm{Ca}^{2+}$ signaling. Curr. Opin. Neurobiol. 1998, 8, 398-404. [CrossRef]

39. Rizzuto, R.; Bernardi, P.; Pozzan, T. Mitochondria as all-round players of the calcium game. J. Physiol. 2000, 529 Pt 1, $37-47$. [CrossRef]

40. Janssen, R.J.; Nijtmans, L.G.; van den Heuvel, L.P.; Smeitink, J.A. Mitochondrial complex I: Structure, function and pathology. J. Inherit. Metab. Dis. 2006, 29, 499-515. [CrossRef] [PubMed]

41. Sharma, L.K.; Lu, J.; Bai, Y. Mitochondrial respiratory complex I: Structure, function and implication in human diseases. Curr. Med. Chem. 2009, 16, 1266-1277. [CrossRef]

42. Mimaki, M.; Wang, X.; McKenzie, M.; Thorburn, D.R.; Ryan, M.T. Understanding mitochondrial complex I assembly in health and disease. Biochim. Biophys. Acta 2012, 1817, 851-862. [CrossRef] [PubMed]

43. Crofts, A.R. The cytochrome bc1 complex: Function in the context of structure. Annu. Rev. Physiol. 2004, 66, 689-733. [CrossRef] [PubMed]

44. Schultz, B.E.; Chan, S.I. Structures and proton-pumping strategies of mitochondrial respiratory enzymes. Annu. Rev. Biophys. Biomol. Struct. 2001, 30, 23-65. [CrossRef] [PubMed]

45. Oyadomari, S.; Mori, M. Roles of CHOP/GADD153 in endoplasmic reticulum stress. Cell Death Differ. 2004, 11, 381-389. [CrossRef]

46. Zinszner, H.; Kuroda, M.; Wang, X.; Batchvarova, N.; Lightfoot, R.T.; Remotti, H.; Stevens, J.L.; Ron, D. CHOP is implicated in programmed cell death in response to impaired function of the endoplasmic reticulum. Genes Dev. 1998, 12, 982-995. [CrossRef] 
47. Oyadomari, S.; Takeda, K.; Takiguchi, M.; Gotoh, T.; Matsumoto, M.; Wada, I.; Akira, S.; Araki, E.; Mori, M. Nitric oxide-induced apoptosis in pancreatic beta cells is mediated by the endoplasmic reticulum stress pathway. Proc. Natl. Acad. Sci. USA 2001, 98, 10845-10850. [CrossRef]

48. Oyadomari, S.; Koizumi, A.; Takeda, K.; Gotoh, T.; Akira, S.; Araki, E.; Mori, M. Targeted disruption of the Chop gene delays endoplasmic reticulum stress-mediated diabetes. J. Clin. Investig. 2002, 109, 525-532. [CrossRef]

49. Matsumoto, M.; Minami, M.; Takeda, K.; Sakao, Y.; Akira, S. Ectopic expression of CHOP (GADD153) induces apoptosis in M1 myeloblastic leukemia cells. FEBS Lett. 1996, 395, 143-147. [CrossRef]

50. McCullough, K.D.; Martindale, J.L.; Klotz, L.O.; Aw, T.Y.; Holbrook, N.J. Gadd153 sensitizes cells to endoplasmic reticulum stress by down-regulating Bcl2 and perturbing the cellular redox state. Mol. Cell Biol. 2001, 21, 1249-1259. [CrossRef]

51. Huang, C.J.; Haataja, L.; Gurlo, T.; Butler, A.E.; Wu, X.; Soeller, W.C.; Butler, P.C. Induction of endoplasmic reticulum stressinduced beta-cell apoptosis and accumulation of polyubiquitinated proteins by human islet amyloid polypeptide. Am. J. Physiol. Endocrinol. Metab. 2007, 293, E1656-E1662. [CrossRef]

52. Huang, C.J.; Lin, C.Y.; Haataja, L.; Gurlo, T.; Butler, A.E.; Rizza, R.A.; Butler, P.C. High expression rates of human islet amyloid polypeptide induce endoplasmic reticulum stress mediated beta-cell apoptosis, a characteristic of humans with type 2 but not type 1 diabetes. Diabetes 2007, 56, 2016-2027. [CrossRef]

53. Gurlo, T.; Rivera, J.F.; Butler, A.E.; Cory, M.; Hoang, J.; Costes, S.; Butler, P.C. CHOP Contributes to, But Is Not the Only Mediator of, IAPP Induced $\beta$-Cell Apoptosis. Mol. Endocrinol. 2016, 30, 446-454. [CrossRef] [PubMed]

54. Cadavez, L.; Montane, J.; Alcarraz-Vizán, G.; Visa, M.; Vidal-Fàbrega, L.; Servitja, J.M.; Novials, A. Chaperones ameliorate beta cell dysfunction associated with human islet amyloid polypeptide overexpression. PLoS ONE 2014, 9, e101797. [CrossRef] [PubMed]

55. Zraika, S.; Hull, R.L.; Udayasankar, J.; Aston-Mourney, K.; Subramanian, S.L.; Kisilevsky, R.; Szarek, W.A.; Kahn, S.E. Oxidative stress is induced by islet amyloid formation and time-dependently mediates amyloid-induced beta cell apoptosis. Diabetologia 2009, 52, 626-635. [CrossRef]

56. Costes, S.; Bertrand, G.; Ravier, M.A. Mechanisms of Beta-Cell Apoptosis in Type 2 Diabetes-Prone Situations and Potential Protection by GLP-1-Based Therapies. Int. J. Mol. Sci. 2021, 22, 5303. [CrossRef] [PubMed]

57. Daval, M.; Gurlo, T.; Costes, S.; Huang, C.J.; Butler, P.C. Cyclin-dependent kinase 5 promotes pancreatic $\beta$-cell survival via Fak-Akt signaling pathways. Diabetes 2011, 60, 1186-1197. [CrossRef] [PubMed]

58. Li, B.S.; Ma, W.; Jaffe, H.; Zheng, Y.; Takahashi, S.; Zhang, L.; Kulkarni, A.B.; Pant, H.C. Cyclin-dependent kinase-5 is involved in neuregulin-dependent activation of phosphatidylinositol 3-kinase and Akt activity mediating neuronal survival. J. Biol. Chem. 2003, 278, 35702-35709. [CrossRef]

59. Wang, C.X.; Song, J.H.; Song, D.K.; Yong, V.W.; Shuaib, A.; Hao, C. Cyclin-dependent kinase-5 prevents neuronal apoptosis through ERK-mediated upregulation of Bcl-2. Cell Death Differ. 2006, 13, 1203-1212. [CrossRef] 